\title{
Netizens' Perspective towards Electronic Money and Its Essence in the Virtual Economy: An Empirical Analysis with Special Reference to Delhi-NCR, India
}

\author{
Mohammed Arshad Khan (iD \\ Department of Accountancy, College of Administrative and Financial Sciences, Saudi Electronic University, \\ Riyadh 11673, Saudi Arabia \\ Correspondence should be addressed to Mohammed Arshad Khan; m.akhan@seu.edu.sa
}

Received 25 June 2021; Revised 12 October 2021; Accepted 18 October 2021; Published 3 November 2021

Academic Editor: M. M. El-Dessoky

Copyright ( $) 2021$ Mohammed Arshad Khan. This is an open access article distributed under the Creative Commons Attribution License, which permits unrestricted use, distribution, and reproduction in any medium, provided the original work is properly cited.

\begin{abstract}
This research attempts to evaluate the ongoing position of the modalities exercised in India concerning digital payments. Largely appraised as a success story in the making, this research examines several instrumental factors in India's digital payment systems. It further extends to identifying the impact of demographic attributes and constructive variables, such as service quality, reliability, satisfaction, and security on digital payment system, Delhi NCR, India. A Google form questionnaire was adopted to collect data through online mode. The researcher collected the primary data from 165 respondents. Purposive sampling method was exercised, along with CFA technique and parameter test used through SPSS (version 25), reliability issue, validity issue, and model fitness achieve through SPSS-AMOS (version 24). The significant peculiarities and analysis are presented further in this research contributing to a precise depiction of findings and then, based on it, the conclusion.
\end{abstract}

\section{Introduction}

Digital payment, quite simply, is a form of carrying out transactions devoid of any physical exchange of money. However, the said transaction is mandatorily performed via the Internet or applications necessitating its employment. It is the principal branch of digitization, comprising the transition of the natives from the physical exchange of money to digital transactions. The parties involved in the said scenario include a payer and a payee. The individual sending the money is the payer, whereas the recipient or the person to whom the money is transferred is the payee. This contemporary form of exchange of money, mandating the Internet for both parties and eliminating hard currency giveand-take in its entirety, is also known as electronic payment. It is, hence, a rapid and highly convenient method of carrying out transactions [1].

This modern-day method of money exchange comprises several modalities in its application of the Internet. These are debit card, credit card, net banking, Unified Payments Interface (UPI), digital wallets, etc. Compared with the typical form of carrying out transactions, which is, through currency notes, the employment of the Internet (hence, the word "digital") separates digital payment from the earlier forms of payments, particularly the barter system. The barter system did not have a justifiable give-and-take format along with the previously exercised forms of payments. Coins and currency notes, later on, amended the problems, which is now superseded by, or surging by and large, electronic payments. One of the logical reasons for amelioration is the recurrent issues found in the system, involving cash falsification, cheque bounce, and signature forgery. However, the transition to digital payment is also not infallible. It raises several doubts about frauds happening due to compromised privacy when carrying out transactions digitally on the Internet.

It is also worth mentioning the intensified Internet use in the present time arising from widespread availability, also 
accommodating cybercriminals. This decade is witnessing extensive use of smartphones (again, differentiating from regular phones for having Internet applications of all kinds) and enormous access to many products and services via e-commerce applications, which natives greatly enjoy as they happily make payments digitally online [2]. The substantial improvements happening continually in the mobile and broadband industry, leading to cutting-edge technology in rapid succession, and Internet speed, thought of unimaginable some time ago, are also instrumental in the greater use of the Internet and the migration of natives from the currency-based exchange of money to digital payments. The movement from paper to digital, however, was not as smooth [3]. The element of trust was sorely missing initially as people only relied on the cash on delivery method, which they were accustomed to. The lack of proper awareness about the various forms of digital payments largely hindered people from using them [4].

Additionally, various myths acted against the use of digital payment methods. Many believed for the banks to deduct high transaction charges for performing transactions digitally, whether by debit card, credit card, or net banking. Some even criticized the means of payment for the likelihood of overspending, provided the extreme ease of convenience in buying products and services. These myths are still largely present amongst the populace of India, calling for the need for adequate literacy on digital payment systems [5]. It is all more prominent when considered India is undergoing a substantial digital revolution. Appropriate digitization of the payment mechanism will be highly rewarding in the definite possibility of an entirely cashless future economy.

It is also imperative to acknowledge the need for the rightful progression of the Indian digital payment system. It is expectedly the most significant factor that defines how the industry looks in the future [6]. With India shifting to digital means, having an agreeable regulatory environment, the advent of next-generation payment service providers and an improved customer experience are the rudimentary factors contributing to India's overall progression in digital payment systems. That is not to say, various facilitators are encouraging in boosting the means of digital payments, allowing the switch from cash-based to the wholly digital economy [7]. Acting as a bridge to solidifying the Indian digital payment systems, these facilitators comprise the successive advancements done in bolstering Internet connectivity on smartphones, nonbanking financial institutions expediting digital means of carrying out transactions, the emergence of financial technology sectors, and the gradual push by the government through various tax incentives [8]. Hence, all of these factors are helping with an assertive situation for the progression of digital payment systems in India.

The various digital payment systems currently exercised in India comprise banking cards (debit/credit card), digital wallets (Paytm, PhonePe, etc.), National Electronic Fund Transfer (NEFT), Unified Payment Interface (UPI), mobile banking, Real Time Gross Settlement (RTGS), Unstructured Supplementary Service Data (USSD), and Aadhar Enabled Payment System (AEPS) [9].

\subsection{Types of Digital Payment}

1.1.1. Banking Cards. The most common types of payment cards are credit cards and debit cards. They are the most easily found and commonly used methods of digital payment. The primary feature of the cards is that they are electronically linked to the holder's bank account and serve as a medium to enable the account holder to purchase commodities without using cash or withdrawing money from an ATM if needed. The cardholder can perform the said actions via a secret code embedded on the backside of the cards, also known as the CVV number (card verification value). The stated number establishes the cardholder's identity and minimises fraud risk [10].

The most influential factors that make banking cards so broadly exercised comprise the ease of convenience and the greater security in making payments. Securitywise, banking cards are quite assuring, most notably, when used in other forms of online payments, such as digital wallets or online transactions [11]. A user may save his or her information on a specific digital app for making digital transactions. The benefit of OTPs (one-time password) ensures, even in the app, either web or mobile-based, at minimal risk. The most recognized banking card payment systems comprise Visa, MasterCard, RuPay, etc. [12]. The usefulness of the cards further extends to making instore purchases via card swiping or a simple tap in POS machines.

1.1.2. Credit Card. In today's times, the credit cards are widely used by the customers as they are providing them the facility of making transactions without debiting their account balances. It is the kind of digital banking card that allows the customer to make purchases against a credit amount, which is lent to the customer by the bank, based on various factors, and hence, it needs to be paid off after a month to 45 days [13]. This variable credit amount lent to the customer is generally called the credit limit. If the customer makes purchases from the card, as per his given credit limit and fails to repay the amount, the bank then begins to charge money on the unpaid credit amount, with interest charges and late fees. However, the bank also rewards loyal customers by increasing the credit limit when they are regularly paying the credit amount. Those having a good credit history also benefit with ease in taking bigger loans from a bank.

1.1.3. Debit Card. The successor to credit card, and currently, the most found banking card amongst the populace, the debit cards, enjoy simple mechanics. As opposed to spending a credit limit provided by the bank, customers can pay as much money in making a digital purchase as per the amount in their account. It is, otherwise, a very convenient method of utilising the saved amount in a bank, akin to a cheque or cash. For the same reasons, these banking cards are also denoted as "cheque cards" or "bank cards." One differentiating advantage of debit cards over credit cards is the greater cash withdrawal limit. A customer can only withdraw cash of a specific limitation, as provided by the bank, from an ATM with a credit card. However, debit 
cards allow customers to draw a much more significant amount (ranging from $\square 25,000$ to $\square 1,00,000$ ) or more, depending on the amount of savings they have in their bank account [14].

1.1.4. Internet Banking. While debit and credit cards are convenient and more regularly used, their most significant limitations include spending a substantial amount, or quite precisely, for corporate use. Internet banking, in this case, becomes the most useful, allowing the customers to make online transactions through a web browser, on a bank's official website, with the help of a login ID and a password. Also, denoted as online banking, virtual banking, or more lately, electronic banking (e-banking), this form of digital payment warrants a steady Internet connection to ensure the process of carrying out transaction is not interrupted. While transaction through debit and credit cards is much quicker, Internet banking has a more elaborate approach, more so for security reasons, and hence, it requires a good Internet connection. Necessary details such as the account number of the person or entity to whom the amount is to be sent are needed, along with the IFSC (Indian Financial System Code). For regular transactions, customers can add beneficiaries to simplify the process of adding account number and IFSC daily [15]. In purchasing through e-commerce websites and opting for Internet banking, the portal automatically redirects to the preferred bank's website, and the banking details mentioned above are not required. At present, nearly every bank has an Internet banking service, and all the payment gateways provide the option of virtual banking options. As specified earlier, NEFT, RTGS, and IMPS are the most commonly exercised ways to transact via online banking [16].

1.1.5. Mobile Banking. Though introduced two decades ago, the application of mobile banking is still scarce, especially when compared with banking cards and Internet banking. However, their usefulness is equally substantial. Also denoted as M-banking, or SMS banking, this is a kind of digital payment service that incorporates almost all Internet banking features (such as issuing a new cheque book or requesting a new debit/credit card, beyond merely paying money) and is exercised via an official banking software application that needs to be installed via app store of a smartphone or tablet [17]. Nearly every bank has its own application, which, as of late, has been used more than Internet banking, provided similar features but significant ease of accessibility. Many people regard this branch of digital payment services as the future of banking, considering the lot of features, and it provides in a clean user interface [18]. The necessity of a smartphone for using M-banking further bolsters digitization.

1.1.6. Digital Wallet. Similar to having a physical wallet, a digital wallet is a virtual case for people to store their money. The application of such wallets is quite identical to modernday debit and credit cards. However, they come conducive in carrying out online and instore transactions with a mere tap, saving plenty of time and inconvenience. Also denoted as an E-wallet, or mobile wallet, this digital payment service needs to be connected with an individual's bank account for carrying out transactions. Some service providers (Paytm, PhonePe, MobiKwik, etc.) allow the customers to exercise the services by adding the amount to their digital wallet by debit or credit cards, hence not necessitating linking their bank account. These wallets comprise two vital components: software, which feeds personal data, ensuring its security and encryption [19]. The second component, information, is a database of data rendered by the users, including their name, shipping address, the preferred mode of payments, amount to be paid, and debit/credit card details [20].

\section{Review of Literature}

In their article, Jayakumar and Vincent Sahayaraj [21] have comprehended the factors that make a customer a happy customer. The paper shows that the customers prefer online banking, ATM etc., but some factors like alertness and consistency affect their level of satisfaction. Customer satisfaction increases towards current banking services if the bank provides more consistent services with value as promised and on time. SBI has successfully implemented substantial factors such as modern equipment, infrastructural amenities, and quality of equipment used. They have been flourishing in achieving an amicable relationship with customers. Most of the article respondents felt that the employees of the SBI are very intense to satisfy their customers.

An electronic wallet (E-wallet) is one of the most current digital payment services that provides its users with the comfort of smooth and simplified transactions via allowing them to store amount or otherwise link their bank account or save credit card details faster and easier checkout or instore payments. The benefits associated with E-wallets, mainly saving time and inconvenience, make the mode of payment favourable among the populace [22]. M-wallet, otherwise known as mobile wallet, is distinguished for various advantages over other modes of payments. The most promising benefits comprise customization and instant communication. However, E-wallets have gained a more significant following their usefulness, particularly in the riding industry and food delivery and bill payments. Hence, they are more used than M-wallet and the other forms of digital payment systems [23]. The peculiarities of E-wallets are not merely advantageous to buyers but also for the traders, who have begun to exercise the mode of payment for its ease of convenience and efficacious cash management, ultimately leading to a reduction in the cost of labour. Physical stores, for instance, have witnessed a steep increase in the exercising of E-Wallets, where the customers can make payments swiftly by scanning the QR code, accommodating for a smooth paperless, cashless experience [24]. Near field communications, otherwise known as NFCsupported devices, are placed close by the payment terminals in physical stores to make the transactions convenient. Henceforth, based on the literature mentioned above, it can 
be surmised that the usefulness of E-Wallets over the other modes of digital payments, mainly for their high flexibility and adaptability and extremely user-friendly process of carrying out transactions via smartphones or tablets.

Abhijit M. Tadse \& Harmeet Singh Nannade [25] tried to analyse the use of Paytm by users of mobile phones and also to find out various issues faced by users of Paytm. The research categorized on the basis of age, purpose of usage, frequency of usage, and average monthly spending on Paytm by the respondents. The study further elaborates that Paytm is quite convenient owing to wide network of partners. This paper concludes that, to improve the transaction efficiency, it needs to work upon the payment gateway as $70 \%$ people face issues with it. In order to cater the requirement of maximum customers, the service needs to improvise as indicated by only $5 \%$ people respondents to have got help every time they encounter a problem in it.

Revathy and Balaji emphasized the crucial role of the rural populace in the rightful progression of the economy, provided they acquire two-third of the total population. The study highlighted how the IT and Communication sector surge is turning fruitful for the nation, surmising a total of $50 \%$ Internet users in India by the end of 2020 . The researcher further necessitated the application of digital wallets, underlining the rural populace and the neediness to spread rightful awareness regarding the usage and benefits of using E-wallets amongst them. The study further specified how the Indian Government took the initiative of spreading appropriate awareness amongst the rural populace towards the usefulness of E-wallets, thoroughly covered under their digitization campaign. The timely implementation of advanced and upcoming technology has been unceasingly low in India instead of the other nations. Though the situation has been highly different in this scenario, the country is progressing shoulder to shoulder with other countries to digitize the economy, explicitly exercising E-wallets. Provided two-thirds of the Indian population constitutes the people residing in the rural areas, the timely exercising of digital payment services will ensure the country becomes a cashless economy in mere few years to come. The urban populace is already well-versed with the usefulness of digital payment systems and hence exercising it. By converting, the rural public towards a cashless system of carrying out business will complete the mission of the Indian Government of having a digitized economy. The best step taken forward in this regard is by the National Payments Corporation of India, accommodating for the E-wallets to function on all mobiles, with or without the availability of the Internet [26].

The researcher highlighted how the rapid increase in the number of smartphone, or otherwise, Internet users gave a rise in the total users exercising digital payment services, who found the alternative of cash convenient and more appealing. This research furthermore emphasized the increasing competition in the domain of digital payment services and the willingness to dominate the massive Indian market, specifying those who entered the territory during the phase of demonetization with the prospect of establishing the company at the right time. Additionally, the study speculated India to become a cashless economy with the appropriate digitization, managing to convert people's behaviour from traditional to the modern-day system of digital payments. The research employed ANOVA to prove no significant variance in consumer perception regarding its demographic factors.

Routray et al. endeavoured to recognize the significant predictors of digital payment services in Middle Eastern Country, Oman. The researcher administered an empirical study for the same and developed a hybrid model through an SEM-neural network model. The study's outcome exhibited that perceived trust, perceived usefulness, and perceived security have a notable impact on the users' intention to exercise digital payment services, specifically $\mathrm{M}$-wallets. In contrast, perceived ease of use does not have a structural effect on the users' intention to exercise M-wallets. Additionally, the study recommended that the service providers maximize social media platforms to produce the rightful awareness among the people for increasing the number of time users spend exercising mobile-based payment services [27].

Tamil Selvi and Balaji [28] strived to recognize whether the demographic profiles of the respondents have any substantial impact on the behavioural intent of the mobile users towards exercising mobile banking services. The researchers, henceforth, carried out an exploratory study for the same in the city of Chennai and Hyderabad. By devising structured questionnaires and distributing them amongst the customers of both public and private banks, the researchers acquired the primary data concerning their viewpoints on the employment of mobile banking. The outcome of the research, thereon, showcased that the performance expectancy, effort expectancy, hedonic motivation, trust, and loyalty are substantially impactful in the behavioural intent of the customers towards exercising mobile banking services.

\section{Research Gap}

The literature review showcased how most of the research is carried out to distinguish the customers' opinion towards the banking payment systems. However, the empirical studies undertaken solely examined the perception of customers towards the digital payment system. This research, however, considered relevant factors such as reliability, service quality, satisfaction, user-friendliness, security, and trustworthy and how they impact the customers.

\section{Objectives of the Study}

The study has the following objectives:

(1) To examine customer opinion concerning the advantageousness of digital payment system in the perspective of service quality, reliability, satisfaction, trustworthy, user-friendly, and security 
(2) To analyse customers' (on the basis of their demographics) perception towards digital payment system and its importance in the banking sector

\section{Hypotheses of the Study}

The study has formulated the following hypotheses:

H01: the mean score of digital payment system does not differ with gender

H02: the mean score of digital payment system does not differ with age

H03: the mean score of digital payment system does not differ with educational qualification

H04: the mean score of digital payment system does not differ with occupational status

H05: the mean score of digital payment system does not differ with income level

\section{Research Methodology}

This research study is based on descriptive-cum-cross section. Primary data are used to obtain an accurate result. The Google Form of the questionnaire was designed and shared online to acquire users' response in Delhi NCR. The questionnaire was divided into two parts: the first part relevant to the respondent background and the second part based on specific statements pertinent to the digital payment system. All statements are further classified into major 6 sets. These sets (reliability, satisfaction, service-quality, userfriendly, trustworthy, and security) established a relationship with the digital payment system. Apart from this, to check the credibility of the constructs was analysed using Cronbach's alpha, which signifies to which the items in the questionnaire were associated with one another [29]. The online data obtained were collected from February to April 2021. A total of 167 replies were obtained through judgement or purposive sampling technique, out of which 165 respondents were selected, and those 165 responses were utilized further for data analysis. For better result, confirm variables were clearly explaining their interrelated construct. CFA technique was accompanied in the study with the help of AMOS (version 24) software. The investigator employed the relevant statistical tools and methods through SPSS (version 25) software to achieve the study's main objectives.

\section{Findings and Discussion}

The essential purpose of this study was to collect primary data by using a closed-ended questionnaire, which was shared with the help of Google Forms. An adequate number of participants showed interest in this online survey. For this study, the purposive sampling method was used. The questionnaire was designed in English for spread and diversification. It consisted of 29 questions divided into two parts. One part related to the respondent's demographic profile, and the other part divided into six factors: viz., reliability, service quality, satisfaction, user friendly, trustworthy, and security. Summated method of rating scale was applied to assess the data from participants. It was performed on a five-point scale basis, starting from "strongly disagree (1) to strongly agree (5).” A total of 167 responses were received, but for the study, 165 responses settled to facilitate data analysis. The SPSS (version 25) and SPSS -AMOS software were used to investigate the collected data quantitatively. This segment comprises the results and findings of the research.

7.1. Background Information of the Respondents. The details of the respondents who filled the questionnaire are provided in this segment. Table 1 demonstrates the responses of the questions connecting to several demographic variables preferred for the study. The statistics showcased here is accumulated from the primary data.

Table 1 represents the participants' demographic information based on their gender, age group, educational qualification, occupational status, and monthly income. It indicates that most of the sample respondents $(70.3 \%)$ were males $(\mathrm{M})$, whereas $29.7 \%$ were females $(\mathrm{F})$. The above data also indicate that most of the respondents $(43 \%)$ belong to the age group of $21-30$ years, $32.1 \%$ were between 31 and 40 years, and $13.3 \%$ belonged of age above 40 years, and the last $11.5 \%$ fall within the age bracket of up to 20 years.

Educational qualification signifies that $18.8 \%$ of respondents belong to undergraduate (U.G), 22.4\% represent graduation $(\mathrm{G}), 26.7 \%$ belong to postgraduation (P.G), $13.9 \%$ represent doctorate (Dr), and $18.2 \%$ represent professional degree holder (PDH). Occupational status represents that $22.4 \%$ of respondent belong to government employees, $29.7 \%$ represent private employees, $19.4 \%$ belong to business or self-employees, and $28.5 \%$ represent students.

The monthly income of the respondents illustrates that $23 \%$ respondents belong to income of Rs. $\leq 10000,19.4 \%$ respondents belong to income of Rs. 10000-25000, 41.8\% respondents belong to income of Rs. 25000-50000, and $15.8 \%$ respondents belong to income of Rs. $<50000$.

7.2. Reliability of the Latent Constructs. According to [30], "Cronbach's alpha is the standard measure of internal correspondence between items in a scale, facilitating its widespread use with Likert Scale-based questions used in the survey. The fundamental objective of reliability testing was to examine the attributes of the scales of measurement and the items for getting the overall index of internal consistency of the scales."

The result of this test is summarized in the Table 2 provided above. The table represents the reliability analysis of the latent constructs used in the study. The consistency interprets the "high internal reliabilities" as the value of Cronbach's alpha ranges between 0.70 and 0.90 . Because of this, it outpaces the threshold limit of 0.70 [31]. Table 2 of reliability result complementary denotes that the coefficient alpha of each latent construct is more than 0.8 , revealing that there is strong internal consistency between the variable in a scale elect for the study.

Bartlett's test is used to resolve the requirement for reducing many statements into a smaller number of factors. 
TABLE 1: Baseline data of the participants $(N=165)$.

\begin{tabular}{|c|c|c|c|c|}
\hline Basis & Categories & $F$ & C.F & $\%$ \\
\hline \multirow{2}{*}{ Gender } & $\mathrm{M}$ & 116 & 116 & 70.3 \\
\hline & $\mathrm{F}$ & 49 & 165 & 29.7 \\
\hline \multirow{4}{*}{ Age group } & Up to 20 years & 19 & 19 & 11.5 \\
\hline & 21-30 years & 71 & 90 & 43 \\
\hline & $31-40$ years & 53 & 143 & 32.1 \\
\hline & 41 and above & 22 & 165 & 13.3 \\
\hline \multirow{5}{*}{$\begin{array}{l}\text { Educational } \\
\text { qualification }\end{array}$} & U.G & 31 & 31 & 18.8 \\
\hline & $\mathrm{G}$ & 37 & 68 & 22.4 \\
\hline & P.G & 44 & 112 & 26.7 \\
\hline & Dr & 23 & 135 & 13.9 \\
\hline & P.D.H & 30 & 165 & 18.2 \\
\hline \multirow{4}{*}{ Occupational status } & Govt. employees & 37 & 37 & 22.4 \\
\hline & Private. employees & 49 & 86 & 29.7 \\
\hline & $\begin{array}{c}\text { Business and self } \\
\text { employees }\end{array}$ & 32 & 118 & 19.4 \\
\hline & Students & 47 & 165 & 28.5 \\
\hline \multirow{4}{*}{ Monthly income } & $\leq$ Rs. 10000 & 38 & 38 & 23 \\
\hline & Rs. 10000 -Rs. 25000 & 32 & 70 & 19.4 \\
\hline & Rs. $25000-$ Rs. 50000 & 69 & 139 & 41.8 \\
\hline & >Rs. 50000 & 26 & 165 & 15.8 \\
\hline \multirow{4}{*}{$\begin{array}{l}\text { Using the digital } \\
\text { payment }\end{array}$} & Less than 1 year & 23 & 23 & 13.9 \\
\hline & $1-5$ years & 96 & 119 & 58.2 \\
\hline & 6-10 years & 44 & 163 & 26.7 \\
\hline & Above 10 years & 2 & 165 & 1.2 \\
\hline
\end{tabular}

TABLE 2: Reliability analysis.

\begin{tabular}{lcc}
\hline Construct & $\alpha$ & No. of items \\
\hline $\begin{array}{l}\text { Perception towards digital payment } \\
\text { system (PDPS) }\end{array}$ & 0.812 & 15 \\
\hline
\end{tabular}

KMO describes the ratio of respondents to number of statements. If the $\mathrm{KMO}$ value is greater than 0.6 , it is accepted for the study. This study revealed 0.813 , which was highly accepted [32]. On the other hand, if Bartlett test $p$ value is less than $5 \%$ alpha, it shows that sampling is adequate. The results of the KMO and Bartlett's test are provided in Table 3.

7.3. Perception of Customer towards Digital Payment System. To analyze whether all the manifest variables are clearly explaining their respective latent construct, the CFA technique was applied by the researcher via AMOS (v-24) software in the present study. Conferring to this research study, to scrutinize the perception of customers towards digital payment system, the leading latent construct that is "perceptions towards digital payment system (PDPS)" has been categorized into five subconstructs. Additionally, each is examined by various statements chosen by the analyst to collect responses from the contributors. It is revealed in Figure 1.

The aforesaid CFA measurement model (Figure 1) portrays the "perception of customer towards digital payment system," the prime latent variable, consistent of six subconstructs: "reliability, service quality, satisfaction, user- friendly, trustworthy, and security." Reliability, the first subconstruct, is consistent with three statements (DPS1, DPS2, and DPS3) expressed by rectangles known as observed variables. Service quality, the second subconstruct, is consistent with two items implied as DPS4 and DPS6. Satisfaction, the third subconstructs, is consistent with two items denoted as DPS7 and DPS8. User-friendly, the fourth subconstruct, measured by three statements implied as DPS10, DPS11, and DPS12. Trustworthy, the fifth subconstruct, is analysed through two items implied as DPS14 and DPS16. Security, the last six subconstructs, is examined by three items denoted as DPS19, DPS20, and DPS21. Fifteen statements were selected out of twenty-one, implying six items were deleted. The reason being it creates a model fitness problem.

Table 4 describes the "Chi-square $\left(\chi^{2}\right)$ " value, i.e., 0.067 , which is greater than $5 \%$ limit, and the "CMIN/DF" value, i.e., 1.238, which is less than the prescribed limit of 3 . These values denote that the deposit sample input is fitting for the model fit. The four indices of goodness, i.e., GFI $=0.927$, AGFI $=0.897, \mathrm{CFI}=0.952$, and $\mathrm{TLI}=0.941$, are more than their recommended limits. It shows that the collected sample dataset is suitable for the model fitness. These values surpass their adequate limits, describing that the model is well-fitted. The two "badness-of-fit" indices denoted by RMSEA $=0.038$ and SRMR $=0.062$ are under the approved limit; it represents that the collected sample input fits the model properly. Hence, it supports that the measurement mentioned above is a well-fitted model.

The term " $e$ " denotes error terms that represent how many parts of variation are unexplained. The standardised regression coefficient represented the arrow leading to the corresponding item, although value over each response item design the squared multiple correlations $\left(R^{2}\right)$ of manifest/measured variables. Tables 4 and 5 serve the analysis portion of the earlier model by analysis of moment structure (v-24).

The upstair examination shows that all the measured variables are significantly connecting to their conforming constructs since their $p$ values are lower than 5\% alpha approved limit. Besides, the standardized regression weight $(\beta)$ of each item is above 0.40 which confirm that the "convergent validity" of the earlier discussed that the CFA measurement model is achieved, and it also illustrates that each manifest variable is highly correlated with its respective latent construct [33].

Table 6 shows the responses of customer towards the digital payment system. Draw out the five-point summated scale that stretches from "strongly disagree (1) to strongly agree (5)." Each statement percentage calculated as per the response provided by customers. This table proffers those which statements more positive feedback received from respondent and vice versa. Statements DPS1, DPS2, DPS3, DPS4, DPS6, DPS7, DPS8, DPS10, DPS11, DPS12, DPS14, DPS16, DPS18, DPS19, and DPS21 shows that respondents are more favourable towards digital payment system. On the other hand, DPS5, DPS9, DPS13, DPS15, DPS17, and DPS20 show that respondent least favourable towards digital payment systems. 
TABLE 3: Sampling adequacy with the help of KMO and Bartlett's test.

\begin{tabular}{lcccc}
\hline Construct & KMO & No. of Items & \multicolumn{2}{c}{ Bartlett's test of sphericity } \\
Approx. Chi-square $\left(\chi^{2}\right)$ & df & $p$ value \\
\hline Perception towards digital payment system (PDPS) & 0.813 & 15 & 509.536 & 105 \\
\hline
\end{tabular}

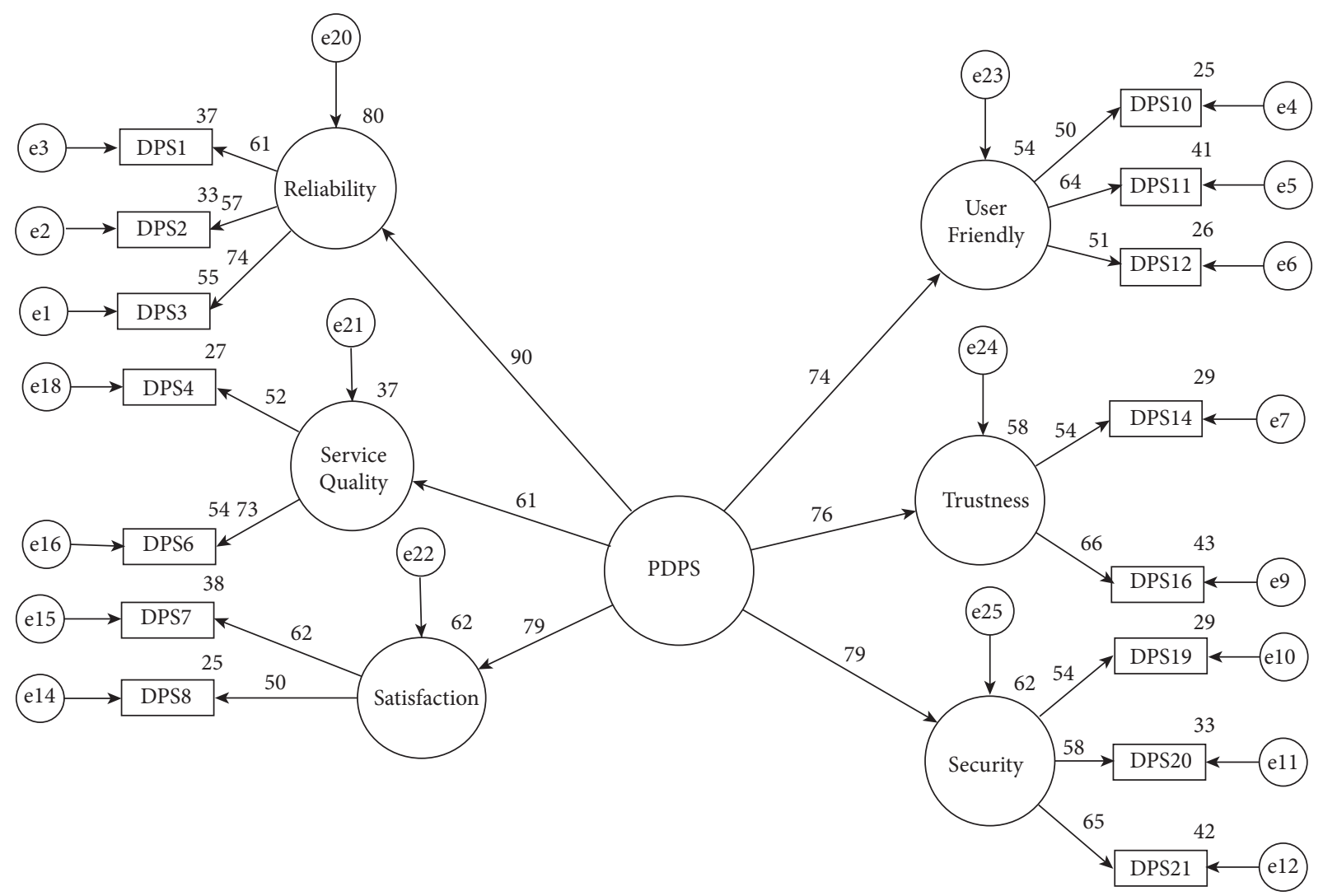

Figure 1: CFA measurement model for PDPS.

TABle 4: Model fit analysis.

\begin{tabular}{lccc}
\hline Name of category & Required fit indices & Acceptable limits & Values obtained \\
\hline & $\chi 2$ & $p$ value $>0.05$ & 0.067 \\
Absolute fit indices & RMSEA & $<0.05$ & 0.038 \\
& SRMR & $<0.09$ & 0.062 \\
& GFI & $>0.90$ & 0.927 \\
Incremental fit indices & AGFI & $>0.80$ & 0.897 \\
& CFI & $>0.90$ & 0.952 \\
Parsimonious fit index & CMIN/DF & $>0.90$ & 0.941 \\
\hline
\end{tabular}

Consistent with the results of the independent sample $t$ test (Table 7), H01 is accepted. The value obtains not significant since the $p$ value (probability value) is more than 0.001. This outcome expresses that gender does not significantly differ from the digital payment system. In some variables such as DPS7, DPS9, DPS12, DPS17, DPS18, and DPS20, $p$ value is less than 0.005 , which means gender significantly differs from the digital payment system.

Consistent with the results of ANOVA (Table 8), H02 is accepted. The value obtains not significant since the $p$ value (probability value) is more than 0.001 . This outcome expresses that age group does not significantly differ from the digital payment system. In some variables such as DPS6, DPS9, DPS11, and DPS14, the $p$ value is less than 0.005, which means the age group significantly differs from the digital payment system.

Consistent with the results of ANOVA (Table 9), H03 is accepted. The value obtains not significant since the $p$ value (probability value) is more than 0.001 . This outcome expresses that educational qualification does not significantly 
TABLe 5: Analysis summary of scalar estimates.

\begin{tabular}{lccc}
\hline Path & B & CR & $p$ value \\
\hline DPS $\longrightarrow$ reliability & 0.90 & 5.691 & $<0.001$ \\
DPS $\longrightarrow$ service quality & 0.61 & 4.051 & $<0.001$ \\
DPS $\longrightarrow$ satisfaction & 0.79 & 4.452 & $<0.001$ \\
DPS $\longrightarrow$ user-friendly & 0.72 & 4.051 & $<.001$ \\
DPS $\longrightarrow$ trustworthy & 0.76 & 4.301 & $<.452$ \\
DPS $\longrightarrow$ security & 0.79 & 6.432 & $<0.001$ \\
Reliability $\longrightarrow$ DPS 1 & 0.61 & 6.118 & $<0.001$ \\
Reliability $\longrightarrow$ DPS 2 & 0.57 & 4.151 & $<0.001$ \\
Reliability $\longrightarrow$ DPS 3 & 0.74 & 3.682 & $<0.001$ \\
Service quality $\longrightarrow$ DPS 4 & 0.52 & 4.131 & $<0.001$ \\
Service quality $\longrightarrow$ DPS 6 & 0.73 & 4.716 & $<0.001$ \\
Satisfaction $\longrightarrow$ DPS 7 & 0.62 & 3.996 & $<0.001$ \\
Satisfaction $\longrightarrow$ DPS 8 & 0.50 & 3.996 & $<0.001$ \\
User-friendly $\longrightarrow$ DPS 10 & 0.50 & 4.430 & $<0.001$ \\
User-friendly $\longrightarrow$ DPS 11 & 0.64 & 4.072 & $<0.001$ \\
User-friendly $\longrightarrow$ DPS 12 & 0.51 & 4.112 & $<0.001$ \\
Trustworthy $\longrightarrow$ DPS 14 & 0.54 & 5.229 & $<0.001$ \\
Trustworthy $\longrightarrow$ DPS 16 & 0.66 & 4.112 & $<001$ \\
Security $\longrightarrow$ DPS 19 & 0.54 & 4.768 & $<0.001$ \\
Security $\longrightarrow$ DPS 20 & 0.58 & 5.001 & $<0.001$ \\
Security $\longrightarrow$ DPS 21 & 0.65 & & $<001$ \\
\hline
\end{tabular}

TABLE 6: Responses of customers towards digital payment system.

\begin{tabular}{|c|c|c|c|c|c|c|}
\hline Code & Variables & S. D (\%) & $\mathrm{D}(\%)$ & N (\%) & A (\%) & S. A (\%) \\
\hline DPS1 & Digital payment system is more user-friendly than previous conventional ones & 0.6 & 0.6 & 21.8 & 40 & 37 \\
\hline DPS2 & Digital payment system is better than the traditional payment system & 0.6 & 2.4 & 13.3 & 52.1 & 31.5 \\
\hline DPS3 & I am more aware related to digital payment system & 15.2 & 3.6 & 0.06 & 46.7 & 33.9 \\
\hline DPS4 & Helpful in saving time, cost, and processing fees & 4 & 12 & 4.6 & 39.4 & 40 \\
\hline DPS5 & Update regarding digital payment service available from time to time & 26 & 30 & 13 & 21 & 10 \\
\hline DPS6 & I find that it is easier to conduct financial transaction through digital mean & 3.9 & 8 & 9 & 49.1 & 30.3 \\
\hline DPS7 & $\begin{array}{c}\text { Digital payment system provides good mechanism, so I feel more comfortable } \\
\text { while performing digital transaction }\end{array}$ & 5.3 & 23 & 8 & 52.7 & 11 \\
\hline DPS8 & There is well-regulated law relating to digital payment system & 5.1 & 13.4 & 5.2 & 52.7 & 23.6 \\
\hline DPS9 & I trust on digital payment system that it will not lead to transaction fraud & 30 & 22 & 21 & 12 & 8 \\
\hline DPS10 & It follows simple steps for completing the particular transactions & 4.1 & 13 & 22 & 30 & 30.9 \\
\hline DPS11 & An electronic payment system is easy to use & 10 & 21 & 20 & 32 & 17 \\
\hline DPS12 & Confidential information is delivered safely to customers & 6 & 21 & 13 & 41 & 19 \\
\hline DPS13 & Track and maintain the digital record of every transaction & 31 & 20.1 & 21 & 15.6 & 12.3 \\
\hline DPS14 & I trust on the ability of a digital payment system to protect my privacy & 21 & 12 & 13 & 33 & 21 \\
\hline DPS15 & Effective complaints and redressal mechanism. & 33 & 24 & 6 & 23 & 14 \\
\hline DPS16 & $\begin{array}{c}\text { Digital payment system provides good mechanism, so I am not concerned } \\
\text { regarding security and data protection issues }\end{array}$ & 15.2 & 19.8 & 11 & 33 & 21 \\
\hline DPS17 & It is providing speedy refund mechanism & 41 & 13 & 17 & 18 & 11 \\
\hline DPS18 & Heavily regulated and protected from any risk & 13 & 10 & 19 & 31 & 27 \\
\hline DPS19 & Transaction take place in immediate time & 14 & 21 & 13 & 41 & 11 \\
\hline DPS20 & The structure and contents of the web site/app are easy to understand & 31 & 21 & 9 & 21 & 18 \\
\hline DPS21 & Digital payment offers cash back and reward points to the users & 10 & 19 & 11 & 43 & 21 \\
\hline
\end{tabular}

differ from the digital payment system. In some variables such as DPS9, DPS14, and DPS18, $p$ value is less than 0.005 , which means educational qualification significantly differ from the digital payment system.

Consistent with the results of ANOVA (Table 10), H04 is accepted. The value obtains not significant since the $p$ value (probability value) is more than 0.001 . This outcome expresses that occupational status does not significantly differ with the digital payment system. In some variables such as DPS3, DPS9, DPS14, DPS15, DPS18, and DPS20, $p$ value is less than 0.005 , which means occupational status significantly differ with the digital payment system.

Consistent with the results of ANOVA (Table 11), H05 is accepted. The value obtains not significant since the $p$ value (probability value) is more than 0.001 . This outcome expresses that monthly income does not significantly differ 
TABLE 7: Gender as independent variable by using independent sample $t$-test.

\begin{tabular}{|c|c|c|c|c|c|c|}
\hline Variable & Gender & $N$ & Std. error & $t$-value & d.f & $p$ value \\
\hline \multirow{2}{*}{ DPS1 } & $\mathrm{M}$ & 116 & 0.073 & 1.895 & 163 & \multirow{2}{*}{0.568} \\
\hline & $\mathrm{F}$ & 49 & 0.122 & 1.831 & 83.896 & \\
\hline \multirow{2}{*}{ DPS2 } & M & 116 & 0.070 & -0.300 & 163 & \multirow{2}{*}{0.248} \\
\hline & $\mathrm{F}$ & 49 & 0.177 & -0.290 & 83.896 & \\
\hline \multirow{2}{*}{ DPS3 } & M & 116 & 0.072 & 2.025 & 163 & \multirow{2}{*}{0.800} \\
\hline & $\mathrm{F}$ & 49 & 0.131 & 1.891 & 83.896 & \\
\hline \multirow{2}{*}{ DPS4 } & M & 116 & 0.081 & 0.115 & 163 & \multirow{2}{*}{0.944} \\
\hline & $\mathrm{F}$ & 49 & 0.118 & 0.115 & 83.896 & \\
\hline \multirow{2}{*}{ DPS5 } & M & 116 & 0.065 & 1.706 & 163 & \multirow{2}{*}{0.974} \\
\hline & $\mathrm{F}$ & 49 & 0.107 & 1.662 & 83.896 & \\
\hline \multirow{2}{*}{ DPS6 } & M & 116 & 0.072 & 0.768 & 163 & \multirow{2}{*}{0.350} \\
\hline & $\mathrm{F}$ & 49 & 0.129 & 0.723 & 83.896 & \\
\hline \multirow{2}{*}{ DPS7 } & $\mathrm{M}$ & 116 & 0.065 & 2.041 & 163 & \multirow{2}{*}{$<0.001$} \\
\hline & $\mathrm{F}$ & 49 & 0.121 & 1.885 & 83.896 & \\
\hline \multirow[b]{2}{*}{ DPS8 } & M & 116 & 0.071 & 0.421 & 163 & \multirow[b]{2}{*}{0.293} \\
\hline & $\mathrm{F}$ & 49 & 0.116 & 0.410 & 83.896 & \\
\hline \multirow{2}{*}{ DPS9 } & $\mathrm{M}$ & 116 & 0.073 & 1.321 & 163 & \multirow{2}{*}{$<0.001$} \\
\hline & $\mathrm{F}$ & 49 & 0.129 & 1.247 & 83.896 & \\
\hline \multirow{2}{*}{ DPS10 } & M & 116 & 0.073 & 0.182 & 163 & \multirow{2}{*}{0.631} \\
\hline & $\mathrm{F}$ & 49 & 0.122 & 0.176 & 83.896 & \\
\hline \multirow{2}{*}{ DPS11 } & M & 116 & 0.065 & 2.376 & 163 & \multirow{2}{*}{0.213} \\
\hline & $\mathrm{F}$ & 49 & 0.103 & 2.349 & 83.896 & \\
\hline \multirow{2}{*}{ DPS12 } & M & 116 & 0.065 & 2.361 & 163 & \multirow{2}{*}{$<0.005$} \\
\hline & $\mathrm{F}$ & 49 & 0.146 & 2.035 & 83.896 & \\
\hline & M & 116 & 0.067 & 1.177 & 163 & \\
\hline DPS13 & $\mathrm{F}$ & 49 & 0.113 & 1.135 & 83.896 & 0.761 \\
\hline & M & 116 & 0.071 & 1.809 & 163 & \\
\hline DPS14 & $\mathrm{F}$ & 49 & 0.137 & 1.653 & 83.896 & 0.161 \\
\hline & $\mathrm{M}$ & 116 & 0.082 & 1.837 & 163 & \\
\hline DPS15 & $\mathrm{F}$ & 49 & 0.119 & 1.881 & 83.896 & 0.814 \\
\hline & $\mathrm{M}$ & 116 & 0.079 & 0.664 & 163 & \\
\hline DPS16 & $\mathrm{F}$ & 49 & 0.137 & 0.632 & 83.896 & 0.079 \\
\hline & M & 116 & 0.055 & 0.747 & 163 & \\
\hline DPS17 & $\mathrm{F}$ & 49 & 0.109 & 0.675 & 83.896 & $<0.001$ \\
\hline & $\mathrm{M}$ & 116 & 0.071 & 2.781 & 163 & \\
\hline DPS18 & $\mathrm{F}$ & 49 & 0.129 & 2.602 & 83.896 & $<0.001$ \\
\hline & M & 116 & 0.066 & 1.044 & 163 & \\
\hline DPS19 & $\mathrm{F}$ & 49 & 0.126 & 0.958 & 83.896 & 0.678 \\
\hline & M & 116 & 0.069 & 1.544 & 163 & \\
\hline DPS20 & $\mathrm{F}$ & 49 & 0.149 & 1.352 & 83.896 & $<0.001$ \\
\hline & M & 116 & 0.069 & 0.762 & 163 & \\
\hline DPS21 & $\mathrm{F}$ & 49 & 0.118 & 0.731 & 83.896 & 0.659 \\
\hline
\end{tabular}

with the digital payment system. In some variables such as DPS6, DPS7, DPS9, DPS14, DPS15, and DPS18, $p$ value is less than 0.005 , which means monthly income significantly differs from the digital payment system.

\section{Limitations and Future Research}

This section points out a few limitations of this research study which should be taken into forethought. First, the sample size in this study is relatively moderate to generalize for India's large population, and in this study, participants of age group response \% rate are more or less similar to each other. So, future studies might take a larger sample size and focus on the youth age group of below 30 years as their perception of customers regarding digital payment might be different. Also, the study participants are associated with the urban class of the population who have more connection to technology. Future research might include the rural class of India in the study as the rural class constitutes a bigger section of the Indian population. If the researcher is unable to reach them through due to technological barriers, then the success of digital system becomes a big question mark. Furthermore, purposive sampling was used to determine the respondents taken in the study. So, in future research, if probability sampling techniques could be used to collect data, and then the generalizability of the findings could be improved.

\section{Future of Digital Payment in India}

The research analysis indicates that the Indian economy will take a substantial time in becoming cashless in its entirety, i.e., with the natives confidently relying on exercising digital 
TABLE 8: Age as independent variable by using one-way ANOVA.

\begin{tabular}{|c|c|c|c|c|c|c|}
\hline \multirow{2}{*}{ Variable } & \multirow{2}{*}{ Age group } & \multicolumn{2}{|c|}{ Sum of square } & \multirow{2}{*}{ d. $\mathrm{f}$} & \multirow{2}{*}{$F$ value } & \multirow{2}{*}{$p$ value } \\
\hline & & Between groups & Within groups & & & \\
\hline DPS1 & $\begin{array}{l}\text { Up to } 20 \text { years } \\
21-30 \text { years } \\
31-40 \text { years } \\
40 \text { and above }\end{array}$ & 2.367 & 105.209 & $\begin{array}{c}3 \\
161\end{array}$ & 1.207 & 0.309 \\
\hline DPS2 & $\begin{array}{l}\text { Up to } 20 \text { years } \\
21-30 \text { years } \\
31-40 \text { years } \\
40 \text { and above }\end{array}$ & 3.340 & 109.109 & $\begin{array}{c}3 \\
161\end{array}$ & 0.161 & 0.922 \\
\hline DPS3 & $\begin{array}{l}\text { Up to } 20 \text { years } \\
21-30 \text { years } \\
31-40 \text { years } \\
40 \text { and above }\end{array}$ & 2.534 & 116.678 & $\begin{array}{c}3 \\
161\end{array}$ & 1.643 & 0.182 \\
\hline DPS4 & $\begin{array}{c}\text { Up to } 20 \text { years } \\
21-30 \text { years } \\
31-40 \text { years } \\
40 \text { and above }\end{array}$ & 1.199 & 83.614 & $\begin{array}{c}3 \\
161\end{array}$ & 1.166 & 0.325 \\
\hline DPS5 & $\begin{array}{c}\text { Up to } 20 \text { years } \\
21-30 \text { years } \\
31-40 \text { years } \\
40 \text { and above }\end{array}$ & 7.446 & 101.063 & $\begin{array}{c}3 \\
161\end{array}$ & 0.769 & 0.513 \\
\hline DPS6 & $\begin{array}{c}\text { Up to } 20 \text { years } \\
21-30 \text { years } \\
31-40 \text { years } \\
40 \text { and above }\end{array}$ & 7.446 & 101.063 & $\begin{array}{c}3 \\
161\end{array}$ & 3.954 & $<0.001$ \\
\hline DPS7 & $\begin{array}{c}\text { Up to } 20 \text { years } \\
21-30 \text { years } \\
31-40 \text { years } \\
40 \text { and above }\end{array}$ & 0.230 & 92.474 & $\begin{array}{c}3 \\
161\end{array}$ & 0.133 & 0.940 \\
\hline DPS8 & $\begin{array}{c}\text { Up to } 20 \text { years } \\
21-30 \text { years } \\
31-40 \text { years } \\
40 \text { and above }\end{array}$ & 1.633 & 97.070 & $\begin{array}{c}3 \\
161\end{array}$ & 0.903 & 0.441 \\
\hline DPS9 & $\begin{array}{l}\text { Up to } 20 \text { years } \\
21-30 \text { years } \\
31-40 \text { years } \\
40 \text { and above }\end{array}$ & 11.883 & 98.929 & $\begin{array}{c}3 \\
161\end{array}$ & 6.446 & $<0.001$ \\
\hline DPS10 & $\begin{array}{l}\text { Up to } 20 \text { years } \\
21-30 \text { years } \\
31-40 \text { years } \\
40 \text { and above }\end{array}$ & 1.613 & 104.362 & $\begin{array}{c}3 \\
161\end{array}$ & 0.830 & 0.479 \\
\hline DPS11 & $\begin{array}{l}\text { Up to } 20 \text { years } \\
21-30 \text { years } \\
31-40 \text { years } \\
40 \text { and above }\end{array}$ & 4.718 & 79.075 & $\begin{array}{c}3 \\
161\end{array}$ & 3.202 & $<0.001$ \\
\hline DPS12 & $\begin{array}{l}\text { Up to } 20 \text { years } \\
21-30 \text { years } \\
31-40 \text { years } \\
40 \text { and above }\end{array}$ & 3.698 & 106.205 & $\begin{array}{c}3 \\
161\end{array}$ & 1.869 & 0.137 \\
\hline DPS13 & $\begin{array}{c}\text { Up to } 20 \text { years } \\
21-30 \text { years } \\
31-40 \text { years } \\
40 \text { and above }\end{array}$ & 0.076 & 90.433 & $\begin{array}{c}3 \\
161\end{array}$ & 0.045 & 0.987 \\
\hline DPS14 & $\begin{array}{c}\text { Up to } 20 \text { years } \\
21-30 \text { years } \\
31-40 \text { years } \\
40 \text { and above }\end{array}$ & 5.543 & 108.239 & $\begin{array}{c}3 \\
161\end{array}$ & 2.748 & $<0.001$ \\
\hline
\end{tabular}


TABle 8: Continued.

\begin{tabular}{|c|c|c|c|c|c|c|}
\hline \multirow{2}{*}{ Variable } & \multirow{2}{*}{ Age group } & \multicolumn{2}{|c|}{ Sum of square } & \multirow{2}{*}{ d. $f$} & \multirow{2}{*}{$F$ value } & \multirow{2}{*}{$p$ value } \\
\hline & & Between groups & Within groups & & & \\
\hline DPS15 & $\begin{array}{c}\text { Up to } 20 \text { years } \\
21-30 \text { years } \\
31-40 \text { years } \\
40 \text { and above }\end{array}$ & 5.642 & 113.782 & $\begin{array}{c}3 \\
161\end{array}$ & 2.547 & 0.058 \\
\hline DPS16 & $\begin{array}{c}\text { Up to } 20 \text { years } \\
21-30 \text { years } \\
31-40 \text { years } \\
40 \text { and above }\end{array}$ & 1.270 & 125.858 & $\begin{array}{c}3 \\
161\end{array}$ & 0.541 & 0.655 \\
\hline DPS17 & $\begin{array}{c}\text { Up to } 20 \text { years } \\
21-30 \text { years } \\
31-40 \text { years } \\
40 \text { and above }\end{array}$ & 1.673 & 67.140 & $\begin{array}{c}3 \\
161\end{array}$ & 1.337 & 0.264 \\
\hline DPS18 & $\begin{array}{l}\text { Up to } 20 \text { years } \\
21-30 \text { years } \\
31-40 \text { years } \\
40 \text { and above }\end{array}$ & 4.318 & 108.130 & $\begin{array}{c}3 \\
161\end{array}$ & 2.143 & 0.097 \\
\hline DPS19 & $\begin{array}{l}\text { Up to } 20 \text { years } \\
21-30 \text { years } \\
31-40 \text { years } \\
40 \text { and above }\end{array}$ & 1.576 & 94.569 & $\begin{array}{c}3 \\
161\end{array}$ & 0.895 & 0.445 \\
\hline DPS20 & $\begin{array}{c}\text { Up to } 20 \text { years } \\
21-30 \text { years } \\
31-40 \text { years } \\
40 \text { and above }\end{array}$ & 5.447 & 113.062 & $\begin{array}{c}3 \\
161\end{array}$ & 2.585 & 0.055 \\
\hline DPS21 & $\begin{array}{l}\text { Up to } 20 \text { years } \\
21-30 \text { years } \\
31-40 \text { years } \\
40 \text { and above }\end{array}$ & 0.852 & 96.785 & $\begin{array}{c}3 \\
161\end{array}$ & 0.472 & 0.702 \\
\hline
\end{tabular}

TABLE 9: Educational qualification as independent variable by using one-way ANOVA.

\begin{tabular}{|c|c|c|c|c|c|c|}
\hline \multirow{2}{*}{ Variable } & \multirow{2}{*}{ Educational qualification } & \multicolumn{2}{|c|}{ Sum of square } & \multirow{2}{*}{ d. $\mathrm{f}$} & \multirow{2}{*}{$F$ value } & \multirow{2}{*}{$p$ value } \\
\hline & & Between groups & Within groups & & & \\
\hline \multirow{5}{*}{ DPS1 } & U. G & & & & \multirow{5}{*}{0.813} & \multirow{5}{*}{0.518} \\
\hline & G & & & 3 & & \\
\hline & P. G & 2.144 & 105.432 & & & \\
\hline & Dr & & & & & \\
\hline & P.D.H & & & 161 & & \\
\hline \multirow{5}{*}{ DPS2 } & U. G & & & & \multirow{5}{*}{1.415} & \multirow{5}{*}{0.231} \\
\hline & G & & & 3 & & \\
\hline & P. G & 3.309 & 93.503 & & & \\
\hline & Dr & & & 161 & & \\
\hline & P.D.H & & & 161 & & \\
\hline \multirow{5}{*}{ DPS3 } & U. G & & & & \multirow{5}{*}{1.123} & \multirow{5}{*}{0.347} \\
\hline & G & & & 3 & & \\
\hline & P. G & 3.072 & 109.377 & & & \\
\hline & Dr & & & & & \\
\hline & P.D.H & & & 161 & & \\
\hline \multirow{5}{*}{ DPS4 } & U. G & & & & \multirow{5}{*}{0.099} & \multirow{5}{*}{0.983} \\
\hline & G & & & 3 & & \\
\hline & P. G & 0.294 & 118.918 & & & \\
\hline & Dr & & & & & \\
\hline & P.D.H & & & 161 & & \\
\hline \multirow{4}{*}{ DPS5 } & U. G & & & & \multirow{4}{*}{1.904} & \multirow{4}{*}{0.112} \\
\hline & $\mathrm{G}$ & & & 3 & & \\
\hline & P. G & 3.854 & 80.958 & & & \\
\hline & $\begin{array}{c}\text { Dr } \\
\text { P.D.H }\end{array}$ & & & 161 & & \\
\hline
\end{tabular}


TABle 9: Continued.

\begin{tabular}{|c|c|c|c|c|c|c|}
\hline \multirow{2}{*}{ Variable } & \multirow{2}{*}{ Educational qualification } & \multicolumn{2}{|c|}{ Sum of square } & \multirow{2}{*}{ d. $f$} & \multirow{2}{*}{$F$ value } & \multirow{2}{*}{$p$ value } \\
\hline & & Between groups & Within groups & & & \\
\hline DPS6 & $\begin{array}{c}\text { U. G } \\
\text { G } \\
\text { P. G } \\
\text { Dr } \\
\text { P.D.H }\end{array}$ & 5.966 & 102.543 & $\begin{array}{c}3 \\
161\end{array}$ & 2.327 & 0.059 \\
\hline DPS7 & $\begin{array}{l}\text { U. G } \\
\text { G } \\
\text { P. G } \\
\text { Dr } \\
\text { P.D.H }\end{array}$ & 1.023 & 91.680 & $\begin{array}{c}3 \\
161\end{array}$ & 0.446 & 0.775 \\
\hline DPS8 & $\begin{array}{c}\text { U. G } \\
\text { G } \\
\text { P. G } \\
\text { Dr } \\
\text { P.D.H }\end{array}$ & 5.556 & 93.147 & $\begin{array}{c}3 \\
161\end{array}$ & 2.386 & 0.053 \\
\hline DPS9 & $\begin{array}{l}\text { U. G } \\
\text { G } \\
\text { P. G } \\
\text { Dr } \\
\text { P.D.H }\end{array}$ & 6.466 & 104.347 & $\begin{array}{r}3 \\
161\end{array}$ & 2.478 & $<0.001$ \\
\hline DPS10 & $\begin{array}{l}\text { U. G } \\
\text { G } \\
\text { P. G } \\
\text { Dr } \\
\text { P.D.H }\end{array}$ & 3.649 & 102.327 & $\begin{array}{c}3 \\
161\end{array}$ & 1.426 & 0.228 \\
\hline DPS11 & $\begin{array}{c}\text { U. G } \\
\text { G } \\
\text { P. G } \\
\text { Dr } \\
\text { P.D.H }\end{array}$ & 1.207 & 82.587 & $\begin{array}{c}3 \\
161\end{array}$ & 0.584 & 0.674 \\
\hline DPS12 & $\begin{array}{l}\text { U. G } \\
\text { G } \\
\text { P. G } \\
\text { Dr } \\
\text { P.D.H }\end{array}$ & 1.213 & 108.691 & $\begin{array}{c}3 \\
161\end{array}$ & 0.446 & 0.775 \\
\hline DPS13 & $\begin{array}{c}\text { U. G } \\
\text { G } \\
\text { P. G } \\
\text { Dr } \\
\text { P.D.H }\end{array}$ & 0.795 & 89.715 & $\begin{array}{c}3 \\
161\end{array}$ & 0.354 & 0.841 \\
\hline DPS14 & $\begin{array}{c}\text { U. G } \\
\text { G } \\
\text { P. G } \\
\text { Dr } \\
\text { P.D.H }\end{array}$ & 11.372 & 102.410 & $\begin{array}{c}3 \\
161\end{array}$ & 4.442 & $<0.001$ \\
\hline DPS15 & $\begin{array}{l}\text { U. G } \\
\text { G } \\
\text { P. G } \\
\text { Dr } \\
\text { P.D.H }\end{array}$ & 4.685 & 119.825 & $\begin{array}{c}3 \\
161\end{array}$ & 1.564 & 0.187 \\
\hline DPS16 & $\begin{array}{c}\text { U. G } \\
\text { G } \\
\text { P. G } \\
\text { Dr } \\
\text { P.D.H }\end{array}$ & 5.004 & 122.123 & $\begin{array}{c}3 \\
161\end{array}$ & 1.639 & 0.167 \\
\hline DPS17 & $\begin{array}{c}\text { U. G } \\
\text { G } \\
\text { P. G } \\
\text { Dr } \\
\text { P.D.H }\end{array}$ & 2.151 & 66.661 & $\begin{array}{c}3 \\
161\end{array}$ & 1.291 & 0.276 \\
\hline
\end{tabular}


TABle 9: Continued.

\begin{tabular}{|c|c|c|c|c|c|c|}
\hline \multirow{2}{*}{ Variable } & \multirow{2}{*}{ Educational qualification } & \multicolumn{2}{|c|}{ Sum of square } & \multirow{2}{*}{ d. $\mathrm{f}$} & \multirow{2}{*}{$F$ value } & \multirow{2}{*}{$p$ value } \\
\hline & & Between groups & Within groups & & & \\
\hline \multirow{5}{*}{ DPS18 } & U. G & & & & & \\
\hline & G & & & 3 & & \\
\hline & P. G & 7.493 & 104.955 & & 2.856 & $<0.001$ \\
\hline & Dr & & & & & \\
\hline & P.D.H & & & 161 & & \\
\hline \multirow{5}{*}{ DPS19 } & U. G & & & & & \\
\hline & G & & & 3 & & \\
\hline & P. G & 1.333 & 94.812 & & 0.562 & 0.690 \\
\hline & Dr & & & 161 & & \\
\hline & P.D.H & & & 161 & & \\
\hline \multirow{5}{*}{ DPS20 } & U. G & & & & & \\
\hline & G & & & 3 & & \\
\hline & P. G & 5.091 & 113.418 & & 1.796 & 0.132 \\
\hline & Dr & & & 161 & & \\
\hline & P.D.H & & & 161 & & \\
\hline \multirow{4}{*}{ DPS21 } & U. G & & & & & \\
\hline & G & & & 3 & & \\
\hline & P. G & 4.385 & 93.251 & & 1.881 & 0.116 \\
\hline & $\begin{array}{c}\text { Dr } \\
\text { P.D.H }\end{array}$ & & & 161 & & \\
\hline
\end{tabular}

TABle 10: Occupational status as independent variable by using one-way ANOVA.

\begin{tabular}{|c|c|c|c|c|c|c|}
\hline \multirow{2}{*}{ Variable } & \multirow{2}{*}{ Occupational status } & \multicolumn{2}{|c|}{ Sum of square } & \multirow{2}{*}{ d. f } & \multirow{2}{*}{$F$ value } & \multirow{2}{*}{$p$ value } \\
\hline & & Between groups & Within groups & & & \\
\hline DPS 1 & $\begin{array}{c}\text { Govt. employee } \\
\text { Private employee } \\
\text { Business/self employee } \\
\text { Students }\end{array}$ & 2.115 & 105.461 & $\begin{array}{c}3 \\
161\end{array}$ & 1.076 & 0.361 \\
\hline DPS 2 & $\begin{array}{c}\text { Govt. employee } \\
\text { Private employee } \\
\text { Business/self employee } \\
\text { Students }\end{array}$ & 1.463 & 95.349 & $\begin{array}{c}3 \\
161\end{array}$ & 0.823 & 0.483 \\
\hline DPS 3 & $\begin{array}{c}\text { Govt. employee } \\
\text { Private employee } \\
\text { Business/self employee } \\
\text { Students }\end{array}$ & 5.502 & 106.946 & $\begin{array}{c}3 \\
161\end{array}$ & 2.761 & $<0.001$ \\
\hline DPS 4 & $\begin{array}{c}\text { Govt. employee } \\
\text { Private employee } \\
\text { Business/self employee } \\
\text { Students }\end{array}$ & 0.898 & 118.314 & $\begin{array}{c}3 \\
161\end{array}$ & 0.407 & 0.748 \\
\hline DPS 5 & $\begin{array}{c}\text { Govt. employee } \\
\text { Private employee } \\
\text { Business/self employee } \\
\text { Students }\end{array}$ & 1.833 & 82.979 & $\begin{array}{c}3 \\
161\end{array}$ & 1.186 & 0.317 \\
\hline DPS 6 & $\begin{array}{c}\text { Govt. employee } \\
\text { Private employee } \\
\text { Business/self employee } \\
\text { Students }\end{array}$ & 4.418 & 104.091 & $\begin{array}{c}3 \\
161\end{array}$ & 2.278 & 0.082 \\
\hline DPS 7 & $\begin{array}{c}\text { Govt. employee } \\
\text { Private employee } \\
\text { Business/self employee } \\
\text { Students }\end{array}$ & 1.509 & 91.194 & $\begin{array}{c}3 \\
161\end{array}$ & 0.888 & 0.449 \\
\hline DPS 8 & $\begin{array}{c}\text { Govt. employee } \\
\text { Private employee } \\
\text { Business/self employee } \\
\text { Students }\end{array}$ & 2.064 & 96.639 & $\begin{array}{c}3 \\
161\end{array}$ & 1.146 & 0.332 \\
\hline
\end{tabular}


TABle 10: Continued.

\begin{tabular}{|c|c|c|c|c|c|c|}
\hline \multirow{2}{*}{ Variable } & \multirow{2}{*}{ Occupational status } & \multicolumn{2}{|c|}{ Sum of square } & \multirow{2}{*}{ d. $\mathrm{f}$} & \multirow{2}{*}{$F$ value } & \multirow{2}{*}{$p$ value } \\
\hline & & Between groups & Within groups & & & \\
\hline DPS 9 & $\begin{array}{c}\text { Govt. employee } \\
\text { Private employee } \\
\text { Business/self employee } \\
\text { Students }\end{array}$ & 8.592 & 102.220 & $\begin{array}{c}3 \\
161\end{array}$ & 4.511 & $<0.001$ \\
\hline DPS 10 & $\begin{array}{c}\text { Govt. employee } \\
\text { Private employee } \\
\text { Business/self employee } \\
\text { Students }\end{array}$ & 1.210 & 104.766 & $\begin{array}{c}3 \\
161\end{array}$ & 0.620 & 0.603 \\
\hline DPS 11 & $\begin{array}{c}\text { Govt. employee } \\
\text { Private employee } \\
\text { Business/self employee } \\
\text { Students }\end{array}$ & 0.774 & 83.020 & $\begin{array}{c}3 \\
161\end{array}$ & 0.500 & 0.683 \\
\hline DPS 12 & $\begin{array}{c}\text { Govt. employee } \\
\text { Private employee } \\
\text { Business/self employee } \\
\text { Students }\end{array}$ & 2.203 & 107.700 & $\begin{array}{c}3 \\
161\end{array}$ & 1.098 & 0.352 \\
\hline DPS 13 & $\begin{array}{c}\text { Govt. employee } \\
\text { Private employee } \\
\text { Business/self employee } \\
\text { Students }\end{array}$ & 1.134 & 89.375 & $\begin{array}{c}3 \\
161\end{array}$ & 0.681 & 0.565 \\
\hline DPS 14 & $\begin{array}{c}\text { Govt. employee } \\
\text { Private employee } \\
\text { Business/self employee } \\
\text { Students }\end{array}$ & 11.833 & 101.949 & $\begin{array}{c}3 \\
161\end{array}$ & 6.229 & $<0.001$ \\
\hline DPS 15 & $\begin{array}{c}\text { Govt. employee } \\
\text { Private employee } \\
\text { Business/self employee } \\
\text { Students }\end{array}$ & 6.994 & 117.515 & $\begin{array}{c}3 \\
161\end{array}$ & 3.194 & $<0.001$ \\
\hline DPS 16 & $\begin{array}{c}\text { Govt. employee } \\
\text { Private employee } \\
\text { Business/self employee } \\
\text { Students }\end{array}$ & 5.134 & 121.994 & $\begin{array}{c}3 \\
161\end{array}$ & 2.258 & 0.084 \\
\hline DPS 17 & $\begin{array}{c}\text { Govt. employee } \\
\text { Private employee } \\
\text { Business/self employee } \\
\text { Students }\end{array}$ & 1.732 & 67.080 & $\begin{array}{c}3 \\
161\end{array}$ & 1.386 & 0.249 \\
\hline DPS 18 & $\begin{array}{c}\text { Govt. employee } \\
\text { Private employee } \\
\text { Business/self employee } \\
\text { Students }\end{array}$ & 6.435 & 106.014 & $\begin{array}{c}3 \\
161\end{array}$ & 3.257 & $<0.001$ \\
\hline DPS 19 & $\begin{array}{c}\text { Govt. employee } \\
\text { Private employee } \\
\text { Business/self employee } \\
\text { Students }\end{array}$ & 0.123 & 96.022 & $\begin{array}{c}3 \\
161\end{array}$ & 0.069 & 0.976 \\
\hline DPS 20 & $\begin{array}{c}\text { Govt. employee } \\
\text { Private employee } \\
\text { Business/self employee } \\
\text { Students }\end{array}$ & 5.807 & 112.702 & $\begin{array}{c}3 \\
161\end{array}$ & 2.765 & $<0.001$ \\
\hline DPS 21 & $\begin{array}{c}\text { Govt. employee } \\
\text { Private employee } \\
\text { Business/self employee } \\
\text { Students }\end{array}$ & 3.076 & 94.561 & $\begin{array}{c}3 \\
161\end{array}$ & 1.746 & 0.160 \\
\hline
\end{tabular}

payment systems and using electronic means of payment. Greater awareness is needed to ensure people in all parts of the country recognize the benefits of carrying out digital transactions through various means. It is imperative to resolve the scarcity of appropriate digital literacy to advance to make India a digitized economy correctly. Despite the currently provided cashback and relevant promotional offers, a steady, dedicated, and genuinely secure payment 
TABLE 11: Monthly income as independent variable by using one-way ANOVA.

\begin{tabular}{|c|c|c|c|c|c|c|}
\hline \multirow{2}{*}{ Variable } & \multirow{2}{*}{ Monthly income } & \multicolumn{2}{|c|}{ Sum of square } & \multirow{2}{*}{ d. $\mathrm{f}$} & \multirow{2}{*}{$F$ value } & \multirow{2}{*}{$p$ value } \\
\hline & & Between groups & Within groups & & & \\
\hline DPS 1 & $\begin{array}{l}\quad \leq \text { Rs. } 10000 \\
\text { Rs. } 10000-\text { Rs. } 25000 \\
\text { Rs. } 25000-\text { Rs. } 50000 \\
>\text { Rs. } 50000\end{array}$ & 1.269 & 106.307 & $\begin{array}{c}3 \\
161\end{array}$ & 0.641 & 0.590 \\
\hline DPS 2 & $\begin{array}{l}\quad \leq \text { Rs. } 10000 \\
\text { Rs. } 10000-\text { Rs. } 25000 \\
\text { Rs. } 25000-\text { Rs. } 50000 \\
>\text { Rs. } 50000\end{array}$ & 1.475 & 95.337 & $\begin{array}{c}3 \\
161\end{array}$ & 0.831 & 0.479 \\
\hline DPS 3 & $\begin{array}{l}\quad \leq \text { Rs. } 10000 \\
\text { Rs. } 10000-\text { Rs. } 25000 \\
\text { Rs. } 25000-\text { Rs. } 50000 \\
>\text { Rs. } 50000\end{array}$ & 2.872 & 109.576 & $\begin{array}{c}3 \\
161\end{array}$ & 1.407 & 0.243 \\
\hline DPS 4 & $\begin{array}{l}\quad \leq \text { Rs. } 10000 \\
\text { Rs. } 10000-\text { Rs. } 25000 \\
\text { Rs. } 25000-\text { Rs. } 50000 \\
>\text { Rs. } 50000\end{array}$ & 2.194 & 117.018 & $\begin{array}{c}3 \\
161\end{array}$ & 1.006 & 0.392 \\
\hline DPS 5 & $\begin{array}{l}\quad \leq \text { Rs. } 10000 \\
\text { Rs. } 10000-\text { Rs. } 25000 \\
\text { Rs. } 25000-\text { Rs. } 50000 \\
\text { > Rs. } 50000 \\
\text { <Rs. } 10000\end{array}$ & 3.552 & 81.261 & $\begin{array}{c}3 \\
161\end{array}$ & 2.346 & 0.075 \\
\hline DPS 6 & $\begin{array}{l}\quad \leq \text { Rs. } 10000 \\
\text { Rs. } 10000-\text { Rs. } 25000 \\
\text { Rs. } 25000-\text { Rs. } 50000 \\
>\text { Rs. } 50000\end{array}$ & 9.793 & 98.716 & $\begin{array}{c}3 \\
161\end{array}$ & 5.324 & $<0.001$ \\
\hline DPS 7 & $\begin{array}{l}\quad \leq \text { Rs. } 10000 \\
\text { Rs. } 10000-\text { Rs. } 25000 \\
\text { Rs. } 25000-\text { Rs. } 50000 \\
>\text { Rs. } 50000\end{array}$ & 4.592 & 88.111 & $\begin{array}{c}3 \\
161\end{array}$ & 2.797 & $<0.001$ \\
\hline DPS 8 & $\begin{array}{l}\quad \leq \text { Rs. } 10000 \\
\text { Rs. } 10000-\text { Rs. } 25000 \\
\text { Rs. } 25000-\text { Rs. } 50000 \\
>\text { Rs. } 50000\end{array}$ & 1.471 & 97.232 & $\begin{array}{c}3 \\
161\end{array}$ & 0.812 & 0.489 \\
\hline DPS 9 & $\begin{array}{l}\quad \leq \text { Rs. } 10000 \\
\text { Rs. } 10000-\text { Rs. } 25000 \\
\text { Rs. } 25000-\text { Rs. } 50000 \\
\text { > Rs. } 50000\end{array}$ & 10.336 & 100.476 & $\begin{array}{c}3 \\
161\end{array}$ & 5.521 & $<0.001$ \\
\hline DPS 10 & $\begin{array}{l}\quad \leq \text { Rs. } 10000 \\
\text { Rs. } 10000-\text { Rs. } 25000 \\
\text { Rs. } 25000 \text {-Rs. } 50000 \\
\text { > Rs. } 50000\end{array}$ & 0.761 & 105.215 & $\begin{array}{c}3 \\
161\end{array}$ & 0.388 & 0.762 \\
\hline DPS 11 & $\begin{array}{l}\quad \leq \text { Rs. } 10000 \\
\text { Rs. } 10000-\text { Rs. } 25000 \\
\text { Rs. } 25000-\text { Rs. } 50000 \\
>\text { Rs. } 50000\end{array}$ & 1.219 & 82.575 & $\begin{array}{c}3 \\
161\end{array}$ & 0.792 & 0.500 \\
\hline DPS 12 & $\begin{array}{l}\quad \leq \text { Rs. } 10000 \\
\text { Rs. } 10000-\text { Rs. } 25000 \\
\text { Rs. } 25000-\text { Rs. } 50000 \\
>\text { Rs. } 50000\end{array}$ & 3.102 & 106.801 & $\begin{array}{c}3 \\
161\end{array}$ & 1.559 & 0.202 \\
\hline DPS 13 & $\begin{array}{l}\quad \leq \text { Rs. } 10000 \\
\text { Rs. } 10000-\text { Rs. } 25000 \\
\text { Rs. } 25000-\text { Rs. } 50000 \\
>\text { Rs. } 50000\end{array}$ & 1.115 & 89.394 & $\begin{array}{c}3 \\
161\end{array}$ & 0.670 & 0.572 \\
\hline DPS 14 & $\begin{array}{l}\quad \leq \text { Rs. } 10000 \\
\text { Rs. } 10000-\text { Rs. } 25000 \\
\text { Rs. } 25000 \text {-Rs. } 50000 \\
>\text { Rs. } 50000\end{array}$ & 8.521 & 105.261 & $\begin{array}{c}3 \\
161\end{array}$ & 4.344 & $<0.001$ \\
\hline DPS 15 & $\begin{array}{l}\quad \leq \text { Rs. } 10000 \\
\text { Rs. } 10000-\text { Rs. } 25000 \\
\text { Rs. } 25000-\text { Rs. } 50000 \\
>\text { Rs. } 50000\end{array}$ & 7.666 & 116.843 & $\begin{array}{c}3 \\
161\end{array}$ & 3.521 & $<0.001$ \\
\hline
\end{tabular}


TABle 11: Continued.

\begin{tabular}{|c|c|c|c|c|c|c|}
\hline \multirow{2}{*}{ Variable } & \multirow{2}{*}{ Monthly income } & \multicolumn{2}{|c|}{ Sum of square } & \multirow{2}{*}{ d. $\mathrm{f}$} & \multirow{2}{*}{$F$ value } & \multirow{2}{*}{$p$ value } \\
\hline & & Between groups & Within groups & & & \\
\hline DPS 16 & $\begin{array}{l}\quad \leq \text { Rs. } 10000 \\
\text { Rs. } 10000-\text { Rs. } 25000 \\
\text { Rs. } 25000 \text {-Rs. } 50000 \\
\quad>\text { Rs. } 50000\end{array}$ & 2.053 & 125.075 & $\begin{array}{c}3 \\
161\end{array}$ & 0.881 & 0.452 \\
\hline DPS 17 & $\begin{array}{l}\quad \leq \text { Rs } 10000 \\
\text { Rs. } 10000-\text { Rs. } 25000 \\
\text { Rs. } 25000 \text {-Rs. } 50000 \\
\quad>\text { Rs. } 50000\end{array}$ & 0.259 & 68.553 & $\begin{array}{c}3 \\
161\end{array}$ & 0.203 & 0.894 \\
\hline DPS 18 & $\begin{array}{l}\quad \leq \text { Rs. } 10000 \\
\text { Rs. } 10000 \text {-Rs. } 25000 \\
\text { Rs. } 25000 \text {-Rs. } 50000 \\
\quad>\text { Rs. } 50000\end{array}$ & 8.334 & 104.114 & $\begin{array}{c}3 \\
161\end{array}$ & 4.296 & $<0.001$ \\
\hline DPS 19 & $\begin{array}{l}\quad \leq \text { Rs. } 10000 \\
\text { Rs. } 10000-\text { Rs. } 25000 \\
\text { Rs. } 25000 \text {-Rs. } 50000 \\
\text { >Rs. } 50000\end{array}$ & 0.761 & 95.385 & $\begin{array}{c}3 \\
161\end{array}$ & 0.428 & 0.733 \\
\hline DPS 20 & $\begin{array}{l}\quad \leq \text { Rs. } 10000 \\
\text { Rs. } 10000 \text {-Rs. } 25000 \\
\text { Rs. } 25000 \text {-Rs. } 50000 \\
>\text { Rs. } 50000\end{array}$ & 3.927 & 114.582 & $\begin{array}{c}3 \\
161\end{array}$ & 1.839 & 0.142 \\
\hline DPS 21 & $\begin{array}{l}\quad \leq \text { Rs. } 10000 \\
\text { Rs. } 10000-\text { Rs. } 25000 \\
\text { Rs. } 25000-\text { Rs. } 50000 \\
\quad>\text { Rs. } 50000\end{array}$ & 3.545 & 94.091 & $\begin{array}{c}3 \\
161\end{array}$ & 2.022 & 0.113 \\
\hline
\end{tabular}

network is needed to adequately boost digital transactions in the country, which will enable absolute transparency in transactions, ultimately leading to the identification and eradication of black money.

\section{Suggestions}

(1) Transaction cost plays a crucial role in encouraging and discouraging at the same time in the adoption of digital payment methods.

(2) Education-related programs are the best way to provide knowledge to customers about how it is beneficial, less costly, and user-friendly.

(3) Security and trustiness are complementary. If users feel secure regarding the online platform, it ultimately creates goodwill or trust in service providers.

\section{Conclusion}

This research thoroughly endeavoured towards understanding the viewpoints of the general people towards online means of payment. It is, hence, discovered that a more significant influence is played by the demographic factors in the appropriate adoption of the various digital payment services, which include age, gender, educational qualification, occupational status, and the level of income. On other hand, factors such as reliability, satisfaction, service quality, user-friendly, trustworthy, and security also have positive impact on customer adoption. The study examines that the user provides positive response towards digital payments. Besides, the research outcome emphasises the various benefits of exercising digital payments, or otherwise, necessitating the neediness to increase e-payments. Digital means of transactions are not merely beneficial concerning the give-and-take of money but also comprise additional benefits. These include timely reminders of unpaid bills, recharges, various cashbacks and rewards scheme, and linking of bank accounts for autopay structure, all leading to greater convenience and efficacy. It is also evident that online means of transactions or digital payment services will become necessary soon. Henceforth, it is imperative for most of the populace, mainly of those belonging to the rural areas, to make the required transition from the traditional means of spending money to modern-day methods that rely on the application of the Internet. It is determined that the online mode of transactions is considerably secure and time-saving, which also accommodates for keeping an easy-to-access record of all the transactions carried out. The continual advancements in the IT and Communications sector have also enhanced the reachability of mobile networks, along with greater availability of electricity and Internet, leading to the increased use of digital services. It can, therefore, be unquestionably stated that the ultimate transaction system would be cashless. There are more significant benefits to be reaped from exercising digital means of payments. Whether it is E-wallets or mobile banking, the modern-day method of transacting allows people to carry out business anywhere, anytime, at their fingertips, with absolute ease of operations. The coming years will bring forward a substantial increase in the use of digital transactions, all ultimately leading to the fulfilment of India's mission of becoming a digitized economy. As more and more advancements are made, 
specifically in the digital sphere, our habits have continuously evolved. It is high time for the natives to move forward from sticking to the cash-based commerce format and switch to the digitized payment structure. Its several advantages include a substantial reduction in the cost of currency management and detecting various kinds of fraudulent activities, strengthening the economic position. Besides, the government's continuous efforts in creating adequate awareness, building necessary trust, and providing a concrete cybersecurity framework and infrastructure are likely to fasten the people's receptiveness towards digital payment systems, which is currently, by and large, facilitated by the constant growth in the number of smartphone users and Internet penetration, in both urban as well as rural areas.

\section{Data Availability}

The data used to support the findings of this study are available from the corresponding author upon request.

\section{Conflicts of Interest}

The author declares that there are no conflicts of interest.

\section{References}

[1] M. Y. Adults, "Factors influencing the use of E-wallet as a payment method among Malaysian young adults," Journal of International Business and Management, vol. 3, no. 2, pp. 111, 2020.

[2] A. M. Banu, N. S. Mohamed, and S. Parayitam, "Online banking and customer satisfaction: evidence from India," Asia-Pacific Journal of Management Research and Innovation, vol. 15, no. 1-2, pp. 68-80, 2019.

[3] F. D. Bocell, E. Sanders, R. Abbott, M. Li, D. Mccutchen, and D. Amtmann, "The impact of unmodeled error covariance on measurement models in structural equation modeling," 2015, https://digital.lib.washington.edu/researchworks/bitstream/ handle/1773/33773/Bocell_washington_0250E_14570.pdf? sequence $=$.

[4] S. Chakraborty and D. Mitra, "A study on consumers adoption intention for digital wallets in India," International Journal on Customer Relations, vol. 6, no. 1, pp. 38-57, 2018.

[5] M. Chauhan and I. Shingari, "Future of e-wallets: a perspective from under graduates," International Journal of Advanced Research in Computer Science and Software Engineering, vol. 7, no. 8, p. 146, 2017.

[6] G. Ghosh, "Adoption of digital payment system by consumer: a review of literature," vol. 9, no. 2, pp. 412-418, 2021.

[7] M. Y. Husain, R. Mustapha, and S. A. Malik, "Review of measurement item of engineering students' learning environment: confirmatory factor analysis," Journal of Technical Education and Training, vol. 6, no. 1, pp. 42-56, 2014.

[8] P. Kalyani, "An empirical study about the awareness of paperless E-currency transaction like E-wallet using ICT in the youth of India," Journal of Management Engineering and Information Technology (JMEIT), vol. 3, no. 3, pp. 2394-8124, 2016.

[9] G Kanimozhi and K. S. Kamatchi, "Security aspects of mobile based E wallet," International Journal on Recent and Innovation Trends in Computing and Communication, vol. 5, no. 6 , pp. 1223-1228, 2017.
[10] S. Khatoon, X. Zhengliang, and H. Hussain, "The mediating effect of customer satisfaction on the relationship between electronic banking service quality and customer purchase intention: evidence from the Qatar banking sector," SAGE Open, vol. 10, no. 2, 2020.

[11] A. Krishnan and R. Ramasamy, "Accessing the construct and content validity of uncertainty business using sem approach-an exploratory study of manufacturing firms," Global Journal of Management and Business Research, vol. 11, no. 12, pp. 1-9, 2011.

[12] P. Lai, "Research methodology for novelty technology," Journal of Information Systems and Technology Management, vol. 15, 2018.

[13] F. Li, H. Lu, M. Hou, K. Cui, and M. Darbandi, "Customer satisfaction with bank services: the role of cloud services, security, e-learning and service quality," Technology in Society, vol. 64, Article ID 101487, 2021.

[14] G. M. Ling, Y. S. Fern, L. K. Boon, and T. S. Huat, "Understanding customer satisfaction of Internet banking: a case study in malacca," Procedia Economics and Finance, vol. 37, no. 16, pp. 80-85, 2016.

[15] L. Lu, "Decoding Alipay: mobile payments, a cashless society and regulatory challenges," Butterworths Journal of International Banking and Financial Law, vol. 33, no. 1, pp. 40-43, 2018.

[16] D. A. Malar, V. Arvidsson, and J. Holmstrom, "Digital transformation in banking: exploring value co-creation in online banking services in India," Journal of Global Information Technology Management, vol. 22, no. 1, pp. 7-24, 2019.

[17] L. Malusare, "Digital payments methods in India : a study of problems and prospects," International Journal of Scientific Research in Engineering and Management (IJSREM), vol. 3, no. 8, pp. 1-7, 2019.

[18] M. Mujinga, "Online banking service quality: a South African E-S-qual analysis," in Lecture Notes in Computer Science (including subseries Lecture Notes in Artificial Intelligence and Lecture Notes in Bioinformatics), vol. 12066, Berlin, Germany, Springer International Publishing, 2020.

[19] D. C. Muthurasu and D. M. Suganthi, "An overview on digital library," Global Journal for Research Analysis, vol. 8, no. 11, pp. 1-2, 2019.

[20] T. M. Nisar and G. Prabhakar, "Exploring the key drivers behind the adoption of mobile banking services," Journal of Marketing Analytics, vol. 5, no. 3-4, pp. 153-162, 2017.

[21] P. Jayakumar and M. V. Sahayaraj, "A study on customer satisfaction of modern banking system," International Journal Advanced Scientific Research and Development, vol. 50, 2016.

[22] P. P. Patil, N. P. Rana, and Y. K. Dwivedi, "Digital payments adoption research: a review of factors influencing consumer's attitude, intention and usage," in Lecture Notes in Computer Science (including subseries Lecture Notes in Artificial Intelligence and Lecture Notes in Bioinformatics), vol. 11195, Berlin, Germany, Springer International Publishing, 2018.

[23] V. K. Research Scholar and M. Sumathy, "Digital payment systems: perception and concerns among urban consumers," vol. 3, no. 6, pp. 1118-1122, 2017.

[24] I. Researcher and B. Franco Maseke, "Journal of Internet banking and commerce the impact of mobile banking on customer satisfaction: commercial banks of Namibia (keetmanshoop) romario gomachab," Journal of Internet Banking and Commerce, vol. 23, no. 2, 2018.

[25] A. M. Tadse, H. Singh Nannade, A. M. Tadse, and H. S. Nannade, "A study on usage of PAYTM," Pune Research Scholar, vol. 3, no. 2, pp. 1-11, 2017. 
[26] C. Revathy and P. Balaji, "Determinants of behavioural intention on E-wallet usage: an empirical examination in amid of COVID-19 lockdown period," International Journal of Management, vol. 11, no. 6, pp. 92-104, 2020.

[27] S. Routray, R. Khurana, R. Payal, and R. Gupta, "A move towards cashless economy: a case of continuous usage of mobile wallets in India," Theoretical Economics Letters, vol. 9, no. 4, pp. 1152-1166, 2019.

[28] R. Tamilselvi and P. Balaji, "The key determinants of behavioural intention towards mobile banking adoption," International Journal of Innovative Technology and Exploring Engineering, vol. 8, no. 10, pp. 1124-1130, 2019.

[29] M. Salah Uddin and A. Yesmin Akhi, "E-wallet system for Bangladesh an electronic payment system," International Journal of Modeling and Optimization, vol. 4, no. 3, pp. 216-219, 2014.

[30] S. Shree, B. Pratap, R. Saroy, and S. Dhal, "Digital payments and consumer experience in India: a survey based empirical study," Journal of Banking and Financial Technology, vol. 5, pp. 1-20, Article ID 0123456789, 2021.

[31] N. Ul Hadia, N. Abdullah, and I. Sentosa, "An easy approach to exploratory factor analysis: marketing perspective," Journal of Educational and Social Research, vol. 6, no. 1, 2016.

[32] A. Upadhayaya, "Electronic commerce and E-wallet," International Journal of Recent Research and Review, vol. 1, pp. 37-41, 2012.

[33] O. Ureche and R. Plamondon, "Digital payment systems for Internet commerce: the state of the art," World Wide Web, vol. 3, no. 1, pp. 1-11, 2000. 